\title{
Influence of Excessive Single Amino Acid Intake to Free Amino Acid Potencies of Chick Organs
}

\section{Excessive Glycine and Free Amino Acid Patterns of Chick Liver}

\author{
Kei-ichiroh Suglmura, Sumimaro C. Ito, Shin-ichi Honda* \\ and Hiroshi Katayama** \\ (Department of Zootechnical Science, Tokyo University of Agriculture, \\ Sakura-ga-oka, Setagaya-ku, Tokyo) \\ (Received for publication on September 8, 1966)
}

Since ALmQUIST et $a l .^{1,3)}$ reported that glycine was an amino acid required by chick for growth, importance of this amino acid in poultry feeding has been emphasized and the biochemical concerns of glycine and its related compounds were also studied by Wixom et al. ${ }^{3}$. On the other hand, the free amino acid level of animal body fluids and organ tissues were appointed as an useful index in the field of protein nutrition, as LoNGENECKER et al.4) proposed a technique to estimate the adequacy of amino acids of dietary protein through measuring the potency of the amino acids in question in plasma of the test animals. The present study was so conducted to inform the free amino acid variety under influence of glycine supplementation to a chick diet.

\section{Experimentals}

A commercial chick feed (table 1) was given to Plymouth Rock male $\times$ White Leghorn female crossbred cockerels. Sixty five test chicks of similar body weight were selected for the experiment comprising five groups differing in feed composition (tables 1 and 2). Livers of the test chick (table 3) were subjected to free amino acid assay. Each group including 10 chicks (commercial feed group, 25 chicks) was housed in a metal cage, room temperature

Table 1. Amino acid contents of the commercial chick feed (g. of each constituent in $100 \mathrm{~g}$. feed)

\begin{tabular}{ll|lc}
\hline Isoleucine & 0.88 & Histidine & 0.99 \\
Leucine & 1.6 & Glutamic acid & 3.2 \\
Lysine & 1.0 & Glycine & 1.1 \\
Methionine & 0.29 & & 21.0 \\
Phenylalanine & 1.1 & Crude protein & 3.0 \\
Threonine & 0.71 & Crude fat & 7.2 \\
Tryptophan & 0.31 & Crude fibre & \\
Arginine & 1.1 & & \\
\hline
\end{tabular}

Six $N$ hydrochloric acid was used to obtain hydrolysate of powder of the feed with an exception that $4 \mathrm{~N}$ sodium hydroxide containing L-cystein hydrochloride was applied to hydrolise for tryptophan assay.

Present address: * Tokyo Office of Nichimen Co., Ltd., Chuo-ku, Tokyo.

** Shimizu Factory of Honen Oil Co., Ltd., Shimizu City, Japan. 
Excessive Glycine and Free Amino Acids of Organs

Table 2. The composition of the basal feed ( $\mathrm{g}$. of each constituent in $100 \mathrm{~g}$. feed)

\begin{tabular}{l|rr|rr}
\hline & $\begin{array}{c}\text { Period of supply } \\
\text { Level } \\
\text { Constituents }\end{array}$ & First to 3rd exptl. weeks & Fourth to 5th exptl. weeks \\
\cline { 2 - 5 } Maize & $16 \%$ & $20 \%$ & $16 \%$ & $20 \%$ \\
Wheat & 64.0 & 58.0 & 65.0 & 58.0 \\
Wheat bran & 9.5 & 9.5 & 12.0 & 12.0 \\
Soybean meal & 5.0 & 5.0 & 5.0 & 5.0 \\
Fish meal & 15.0 & 15.0 & 11.0 & 11.0 \\
Alfalfa meal & 2.0 & 8.0 & 1.5 & 9.5 \\
Supplemented vitamins, minerals etc.* & 3.0 & 3.0 & 3.0 & 3.0 \\
\hline Crude protein & 1.5 & 1.5 & 1.5 & 1.5 \\
Glycine(assayed) & 16.1 & 21.1 & 15.8 & 21.9 \\
\hline
\end{tabular}

For preparation of glycine added feeds, $4 \mathrm{~g}$ of reagent grade glycine and $96 \mathrm{~g}$ of the above specified basal feeds were mixed.

* The following substances were contained in $1.5 \mathrm{~g}$ of the supplementary compartment: $0.80 \mathrm{~g}$ of calcium-carbonate, $0.25 \mathrm{~g}$ of sodium chloride, $0.30 \mathrm{mg}$ of thiamine, $1.0 \mathrm{mg}$ of riboflavin, $0.20 \mathrm{mg}$ of nicotinic acid, $14 \mathrm{mg}$ of choline chloride, $0.55 \mathrm{mg}$ of calcium pantothenate, $0.10 \mathrm{mg}$ of folic acid, 25,000 IU of vitamin A, 5,000 IU of vitamin $D_{3}, 2.2 \mathrm{mg}$ of chlortetracyclin (drug), $0.10 \mathrm{~g}$ of nitrofuran deriv. (anti coccidiosis drug), $31 \mathrm{mg}$ of $\mathrm{Cu}, 300 \mathrm{mg}$ of $\mathrm{Fe}, 20 \mathrm{mg}$ of $\mathrm{Zn}, 3 \mathrm{mg}$ of $\mathrm{Co}$ and $830 \mathrm{mg}$ of $\mathrm{Mn}$.

Table 3. The test chick groups for the liver amino acid assay (liver of the chicks fed the diet tabulated here)

(I) Commercial chick feed* group (one week after hatching)

\begin{tabular}{l|l}
\hline $\begin{array}{c}\text { Third experimental week } \\
\text { (4 weeks after hatching) }\end{array}$ & $\begin{array}{l}\text { Fifth experimental week } \\
\text { (6 weeks after hatching) }\end{array}$ \\
\hline (II) Basal feed** of $16 \%$ protein & (VI) The feed same as (II) \\
(III) The feed (II) plus $4 \%$ additional & (VII) The feed same as (III) \\
glycine & (VIII) The feed same as (IV) \\
(IV) Basal feed*** of $20 \%$ protein & (IX) The feed same as (V) \\
$\begin{array}{l}\text { (V) The feed (IV) plus } 4 \% \text { additional } \\
\text { glycine }\end{array}$
\end{tabular}

* Specified in Table 1

** and *** Specified in Table 2

varying from 25 to $29^{\circ} \mathrm{C}$ during the periods of the experiment and the test chicks were allowedl to take water and the feeds ad libitum. Body weight and feed consumption were recorded every 3 to 4 day period. Livers of 2 or 3 chicks of each group were removed after drainage of blood from carotid artery after $2 \mathrm{hr}$ fasting and subsequent light anesthetization with ether. The removed livers were weighed and heated in test tubes containing boiling distilled water. Heating was continued for further $20 \mathrm{~min}$ in a boiling water bath. Time consumption for removal and weighing of the subjected liver was limited within 6 min to minimize the post-mortem change of the tissue. The boiled liver was treated by a homogenizer with deproteinizing agent of $0.6 \mathrm{~N}$ sulfuric acid and $10 \%$ sodium tungstate aqueous solution $(7: 5$ in volume, mixed before use) according to the prescription by SchuRR et al. ${ }^{5}$. The filtrate obtained from the deproteinized suspension thus obtained was adjusted to $\mathrm{pH} 6.8$ with dilute sodium hydroxide solution and filled to an aliquot for amino acid assay. The microbiological 
assay method using lactic acid bacteria was applied to the amino acid determination throughout the study. Liquid culture, titrating method on the uniform medium, was availably used for this purpose. Streptococcus faecalis R (ATCC 8043) was used as the test organism for threonine assay, Leuconostoc citrovorum 32 (ATCC 8081) for alanine and histidine and Leuconostoc mesenteroides P-60 (ATCC 8042) for other 15 amino acids.

\section{Results and Discussion}

As shown in table 4, weekly body weight gain and feed efficiency ( $\frac{\text { weekly gain } \times 100}{\text { feeds amts. consumed }}$ ) showed a slight difference between $16 \%$ and $20 \%$ protein feed groups throughout the period of the feeding, the former being slightly inferior throughout the almost all stages of the growth. Wider depression of the weight gains was observed in glycine added feed groups throughout both the protein levels. But the difference in weekly gain was found to be wider at earlier stages of the growth (1st to 4 th experimental weeks). The growth depression showed a tendency to be recovered at the later stage of the growth from the 5th experimental week, even not recognized significantly because of rather wider standard deviation of the figure of each week. No fatality of the test chicks was recorded throughout the experiment. The growth retardation and paralytic symptoms observed in the test chicks fed the glycine added feeds are assumed to be due to the known toxic nature of this amino acid.

Free amino acids of the livers are shown in table 5. In the observation at the 3rd experimental week, the values of glycine of groups III and V (specified in table 3) were

Table 4. Body weight gain (weekly) and the gain per feed consumed

\begin{tabular}{|c|c|c|c|c|}
\hline \multirow{3}{*}{$\begin{array}{l}\text { Exptl. } \\
\text { weeks }\end{array}$} & \multicolumn{4}{|c|}{ Weekly Body Weight Gain } \\
\hline & \multicolumn{2}{|c|}{ Sixteen $\%$ protein } & \multicolumn{2}{|c|}{ Twenty $\%$ protein } \\
\hline & Basal & Basal + glycine & Basal & Basal+glycine \\
\hline $1 \mathrm{st}$ & $60 \pm 5$ & $6 \pm 17$ & $68 \pm 9$ & $20 \pm 4$ \\
\hline $2 \mathrm{nd}$ & $84 \pm 12$ & $39 \pm 12$ & $81 \pm 8$ & $41 \pm 3$ \\
\hline $3 r d$ & $76 \pm 6$ & $56 \pm 11$ & $89 \pm 19$ & $67 \pm 8$ \\
\hline 4 th & $90 \pm 14$ & $65 \pm 25$ & $84 \pm 3$ & $75 \pm 10$ \\
\hline 5 th & $70 \pm 9$ & $96 \pm 8$ & $119 \pm 6$ & $102 \pm 2$ \\
\hline (6th) & $70 \pm 8$ & $75 \pm 4$ & $42 \pm 18$ & $55 \pm 4$ \\
\hline \multirow[t]{2}{*}{ (7th) } & $58 \pm 10$ & $67 \pm 8$ & $69 \pm 3$ & $59 \pm 2$ \\
\hline & \multicolumn{4}{|c|}{ (Gain/Feed consumed) $\times 100$} \\
\hline lst & 47 & 8 & 43 & 26 \\
\hline $2 \mathrm{nd}$ & 36 & 27 & 33 & 31 \\
\hline $3 \mathbf{r d}$ & 27 & 31 & 28 & 39 \\
\hline 4 th & 24 & 23 & 19 & 25 \\
\hline 5 th & 12 & 27 & 28 & 30 \\
\hline$(6 \mathrm{th})$ & 16 & 18 & 8 & 14 \\
\hline$(7 \mathrm{th})$ & 12 & 17 & 15 & 15 \\
\hline
\end{tabular}

Figures of 6 th and 7 th experimental weeks were obtained from chicks having remained after amino acid assay experiment was completted (2 or 3 chicks). 
Excessive Glycine and Free Amino Acids of Organs

Table 5. Free amino acid values in the chick liver $(\gamma / \mathrm{g}$ raw basis)

\begin{tabular}{|c|c|c|c|c|c|c|c|c|c|}
\hline \multirow{2}{*}{$\underbrace{\begin{array}{r}\text { Time } \\
\text { period and } \\
\text { feeds }\end{array}}_{\text {Amino acids }}$} & \multirow{2}{*}{$\left|\begin{array}{c}(I) \\
\text { one } \\
\text { week } \\
\text { after } \\
\text { hatching }\end{array}\right|$} & (II) & (III) & (IV) & (V) & (VI) & (VII) & (VIII) & (IX) \\
\hline & & $\begin{array}{l}\text { Thirc } \\
\text { basal }\end{array}$ & $\begin{array}{l}\text { d experin } \\
\text { basalt } \\
\text { glycine }\end{array}$ & basal & $\begin{array}{l}\text { Neek } \\
\text { basal+ } \\
\text { glycine }\end{array}$ & $\begin{array}{r}\text { Fift } \\
\text { basal }\end{array}$ & $\begin{array}{l}\text { experi } \\
\text { basalt } \\
\text { glycine }\end{array}$ & $\begin{array}{l}\text { mental } \\
\text { basal }\end{array}$ & $\begin{array}{l}\text { week } \\
\text { basal+ } \\
\text { glycine }\end{array}$ \\
\hline Glycine & 71 & 67 & 350 & 59 & 240 & 180 & 180 & 110 & 140 \\
\hline Alanine & 24 & 28 & 29 & 22 & 30 & 63 & 67 & 58 & 62 \\
\hline Arginine* & 26 & 22 & 33 & 27 & 24 & 86 & 53 & 71 & 54 \\
\hline Aspartic acid & 340 & 370 & 390 & 350 & 440 & 510 & 290 & 520 & 490 \\
\hline Cystine & - & 7.6 & 15 & 12 & 6.7 & 24 & 17 & 18 & 17 \\
\hline Glutamic acid & 340 & 380 & 550 & 410 & 490 & 740 & 660 & 690 & 640 \\
\hline Histidine* & 14 & 47 & 21 & 19 & 22 & 57 & 74 & 63 & 49 \\
\hline Isoleucine* & 24 & 23 & 22 & 26 & 19 & 46 & 38 & 50 & 33 \\
\hline Leucine* & 59 & 43 & 48 & 60 & 49 & 80 & 76 & 80 & 84 \\
\hline Lysine* & 30 & 49 & 64 & 68 & 43 & 74 & 62 & 120 & 77 \\
\hline Methionine* & 25 & 29 & 44 & 33 & 32 & 29 & 42 & 37 & 33 \\
\hline Phenylalanine* & 21 & 25 & 31 & 27 & 28 & 43 & 41 & 43 & 29 \\
\hline Proline & 130 & 130 & 190 & 130 & 140 & 210 & 130 & 190 & 190 \\
\hline Serine & 180 & 170 & 310 & 150 & 330 & 190 & 210 & 270 & 240 \\
\hline Threonine* & 140 & 120 & 250 & 130 & 110 & 250 & 150 & 170 & 190 \\
\hline Tryptophan* & 15 & 19 & 20 & 27 & 20 & 34 & 32 & 36 & 24 \\
\hline Tyrosine & 18 & 19 & 19 & 15 & 24 & 39 & 37 & 43 & 30 \\
\hline Valine* & 42 & 42 & 70 & 45 & 50 & 70 & 55 & 78 & 54 \\
\hline Total & 1,499 & 1,592 & 2,456 & 1,610 & 2,098 & 2,725 & 2,214 & 2,647 & 2,436 \\
\hline $\begin{array}{l}\text { Percentage of } 10 \\
\text { essentials } \\
\text { (asterisked) in } \\
\text { total }\end{array}$ & 26 & 26 & 25 & 29 & 19 & 28 & 28 & 28 & 26 \\
\hline
\end{tabular}

evidently higher than those of the groups II and IV. The increase of glycine value (the values obtained from the glycine added group being subtracted by those from the none additional glycine group) were $3.7 \mu \mathrm{mol}$ ( $16 \%$ protein feed) and $2.4 \mu \mathrm{mol}$ ( $20 \%$ protein feed). The values of serine were also found to increase in the experiments III and V, the increases being computed as 1.3 and $1.7 \mu \mathrm{mol}$ respectively in 16 and $20 \%$ protein feed groups. The total of the 18 free amino acids were approximately $1,500 \mathrm{r} / \mathrm{g}$ in I, II and IV, and it surpassed $2,000 \mathrm{r} / \mathrm{g}$ in other tests. No marked change assumed to be due to the addition of glycine was revealed in any of the amino acids assayed except those two mentioned above. In gross observation, the feature of the free amino acid was found to be reasonable when compared with those values in previous report on liver ${ }^{6}$, characterized with higher glutamic acid, aspartic acid, proline and threonine valves and lower cystine value. Ten essentials in the 18 total were about 25 to $28 \%$ (with an exception in the experiment $\mathrm{V}$ ). Although glycine and serine were observed to increase conspicuously in glycine added groups at 3rd experimental week, the 5th experimental subjects revealed increase neither of glycine nor of serine. For interpretation of the results, further experiments are necessitated.

Biochemical interconversion between glycine and serine was already well studied ${ }^{7)}$, but the reason of the discrepancy of the behavior of alteration of glycine and serine amount between 


\section{Sưgimura - Ito - Honda - Katayama}

the observations in both the 3rd and 5th experimental weeks can not be explained by this experiment. Variety of glycine requirement during the experiment, change of tolerance through completion of liver function and domestication to this amino acid could be pointed out to understand the findings described here. B Vitamins, especially pyridoxine phosphate supplied to the test chicks are considered to fulfil the requirement enlisted in NRC standards, while the requirements possibly vary under the condition of inadequate balance of dietary amino acids. SWEndSEID $e t a{ }^{8}{ }^{8}$ demonstrated the relationships of these amino acids to which pyridoxine phosphate concerned. The relationships between growth of the test chicks and potencies of any amino acid in question in organ tissues as well as plasma should be necessarily studied in further works.

\section{Summary}

Test chicks were allowed to take the following feeds: One commercial chick feed for starting chick 1 week after hatching, two basal feeds containing 16 and $20 \%$ protein and two feeds of $4 \%$ glycine added to each of the basal feeds. Free amino acids of liver of the chicks: thus maintained were determined by microbiological assay to which those of the standard feed, $4 \%$ glycine added feed groups were subjected. Among the free amino acid values of liver of the test chicks, free glycine and serine value in glycine added feeds in the 3rd week subjects were found to increase markedly. No other systematic alteration in the free amino acid values was observed throughout the study. Relationships among the growth gain, potencies of the amino acids in question and variations in the behavior of the amino acids in the week age were discussed.

\section{Acknowledgment}

The authors are indebted to Dr. H. Taira, Dr. N. Hoshino and Mrs. H. Taira of Food Research Institute, Ministry of Agriculture and Forestry for their advices and helps to carry out this experiment. To Aji-no-moto Co., Ltd., the authors thanks are also due for contribution in supply of amino acid reagents.

\section{References}

1) Almquist, H.J. and E. Mecchi (1940)

J. Biol. Chem., 135: 355-356.

2) Almquist, H.J. and E. Mecchr (1942)

Proc. Soc. Exptl. Biol. Med., 49: 541-543.

3) Wixom, R.L., G.E. Pipkin, J.H. Wikman and P.L. Day (1958) J. Nutrition, 64: $13-31$.

4) Longenecker, J.B. and N.L. Hause (1961) Am. J. Clin. Nutrition, 9: 356-362.

5) Schurr, P.E., H.J. Thompson, L.M. Henderson and C.A. Elvehjem (1950) J. Biol. Chem., 182: $29-37$.

6) Sugimura, K. and Y. Gendo (1965) Shokuryo Kenkyusho Hokoku, No. 19: 208-215.

7) SAKami, W. (1948) and (1949) J. Biol. Chem., 176: 995-996 and 178: 519-520.

8) SWEndsetd, M.E., J. Villalobos and B. Friedrich (1964) J. Nutrition, 82: 206-208. 
Excessive Glycine and Free Amino Acids of Organs

\title{
単一アミノ酸過剩投与の幼雊器官遊離アミノ酸パターンに及ぼす影響
}

I. 過剩グリシン投与と幼解肝の遊離つミノ酸

\author{
杉村敬一郎・伊藤澄麿・本多真一・片山洋
}

(東京農業大学畜産学科)

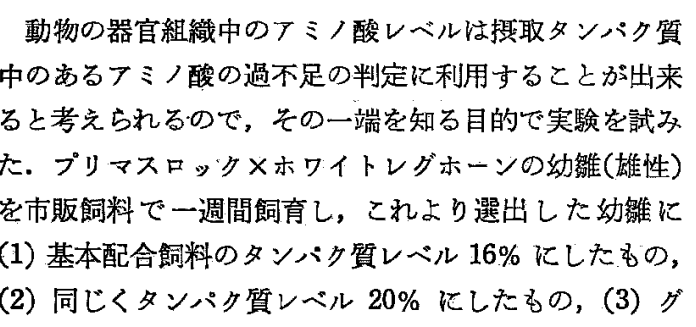
リシン $4 \%$ を(1) に混じたもの,グリシン $4 \%$ を(2) に混じたもの，の4種類を群別に投与して飼育し，この 食慨開始後第 3 週就よび第5 週でそれぞれ肝の遊離つミ ノ酸 18 種を微生物法で測定した. 全般に $16 \%$ タンパク
質の群は 20\%のものよりわずが成長が劣つたが，4\% グリシンのものは更にそれぞれ著しく成育が遅滞した。 しかし，週問成長量怯第 5 週より回復の傾向定示した。 䀒中遊離了ミノ酸のうちグリシンおよびゼリンが第 3 週 の例においては，グリシン過剩投与群において著しく堌 量することが観察されたが，第 5 週の例では增量が認め られなかった，その他のアミノ酸ではグリシン過剩投与 によって系統的な增量または減量を示したるのはなかっ た. これらの知見と幼雔の成長量との関連などに関して 論述した。 